\title{
INTERPROFESSIONAL COLLABORATIVE PRACTICE (IPCP)
}

\section{Interprofessional Collaborative Practice (IPCP)}

Praktik kolaboratif interprofesional dalam layanan kesehatan terjadi ketika banyak petugas kesehatan dari latar belakang profesional yang berbeda memberikan layanan komprehensif dengan bekerja bersama pasien, keluarga mereka, wali dan masyarakat untuk memberikan layanan perawatan dengan kualitas terbaik di seluruh rangkaian. (Organisasi Kesehatan Dunia, 2010, hal.13)

Worker Petugas kesehatan siap praktik kolaboratif adalah seseorang yang telah belajar cara bekerja dalam tim interprofesional dan kompeten untuk melakukannya. Praktik kolaboratif terjadi ketika banyak petugas kesehatan dari latar belakang profesional yang berbeda bekerja bersama dengan pasien, keluarga, pengasuh dan masyarakat untuk memberikan perawatan dengan kualitas terbaik. Ini memungkinkan petugas kesehatan untuk melibatkan setiap individu yang keterampilannya dapat membantu mencapai tujuan kesehatan setempat. Kolaborasi antarprofesional adalah proses mengembangkan dan memelihara hubungan kerja antarprofesional yang efektif dengan pelajar, praktisi, pasien / klien / keluarga dan masyarakat untuk memungkinkan hasil kesehatan yang optimal. Elemen kolaborasi termasuk rasa hormat, kepercayaan, pengambilan keputusan bersama, dan kemitraan (Kolaborasi Kesehatan Interprofessional Kanada (CIHC).

Manfaat praktik kolaboratif

Praktik kolaboratif Praktik kolaboratif dapat meningkatkan:

1. Akses ke layanan kesehatan yang terkoordinasi

2. Penggunaan sumber daya klinik spesialis yang sesuai

3. Hasil kesehatan untuk orang dengan penyakit kronis

4. Perawatan dan keamanan pasien

Praktik kolaboratif dapat menurun:

1. Komplikasi total pasien

2. Lama tinggal di rumah sakit

3. Ketegangan dan konflik di antara pengasuh

4. Pergantian staf

5. Penerimaan di rumah sakit

6. Tingkat kesalahan klinis

7. Tingkat kematian

\section{Identifikasi dan terapkan kompetensi praktik kolaboratif}

Kolaborasi Kesehatan Interprofessional Kanada (CIHC) telah mengembangkan Kerangka Kerja Kompetensi Interprofesional Nasional yang menjelaskan kompetensi yang diperlukan untuk kolaborasi antarprofesional yang efektif. Enam domain kompetensi menyoroti pengetahuan, keterampilan, sikap, dan nilai-nilai yang bersama-sama membentuk penilaian yang penting untuk praktik kolaboratif antarprofesional. Domain-domain ini adalah:

1. Klarifikasi Peran

2. Tim Berfungsi

3. Pasien / Klien / Keluarga / Perawatan yang Berpusat pada Komunitas

4. Kepemimpinan Kolaboratif 


\section{TINJAUAN PUSTAKA}

5. Komunikasi Interprofesional

6. Resolusi Konflik Antarprofesional

Informasi lebih lanjut tentang Kerangka Kompetensi Interprofesional Kolaboratif Nasional Kesehatan Interprofessional Kanada. College of Health Disciplines di University of British Columbia telah mengembangkan serangkaian modul online berdasarkan Kerangka Kompetensi Interprofesional Nasional CIHC. Dalam seri modul ini, IPC on the Run, setiap modul membahas salah satu dari enam domain kompetensi.

\section{Membimbing Pembelajaran Interprofessional}

Ada sejumlah cara untuk membimbing siswa berpikir tentang praktik kolaboratif antarprofesional. Ini termasuk:

1. Memberikan kesempatan bagi siswa untuk menggambarkan peran mereka

2. Memberikan kesempatan bagi siswa untuk membandingkan peran mereka dengan peran profesional kesehatan lainnya

3. Mendorong siswa dari berbagai profesi untuk belajar dengan, dari, dan tentang satu sama lain

4. Memberikan kesempatan untuk berdiskusi tentang masalah yang dihadapi oleh tim interprofesional

5. Mendorong eksplorasi bagaimana konflik terkait dengan masalah ini dapat dikelola

6. Membimbing diskusi tentang hubungan antara kolaborasi antarprofesional dan perawatan pasien / klien / keluarga / masyarakat

7. Menjelaskan mengapa pendidikan interprofesional dan praktik kolaboratif penting dalam profesi dan lingkungan kerja Anda

8. Membuat model untuk siswa interaksi positif Anda dengan profesional lain dan anggota tim

Sebagai pembimbing, Anda juga dapat mengajukan pertanyaan kepada siswa Anda untuk mempromosikan pemikiran kritis dan penyelesaian masalah seputar isu-isu dalam praktik kerja sama antarprofesional. Pertanyaan-pertanyaan berikut, berdasarkan enam kompetensi Kerangka Kerja Interprofesional Nasional, dapat membantu memandu diskusi dan refleksi tentang interprofesional, pasien kolaboratif / klien / keluarga / perawatan yang berpusat pada masyarakat:

Klarifikasi peran:

Apa pengetahuan / keterampilan unik yang dibawa oleh penyedia yang berbeda ke meja?

Apa saja sterotip dan asumsi yang dibuat orang tentang berbagai profesi?

Apa saja persamaan dan perbedaan antara berbagai profesi?

Apakah ada peran yang tumpang tindih? Bagaimana Anda mengatasinya?

Resolusi konflik:

Keadaan apa yang menyebabkan konflik dalam tim?

Bagaimana tim mengelola konflik?

Bagaimana konflik di antara anggota tim mempengaruhi perawatan klien?

Kepemimpinan kolaboratif:

Bagaimana anggota tim dilibatkan dalam pengambilan keputusan?

Bagaimana Anda akan melibatkan anggota tim dalam pengambilan keputusan?

Apakah peran kepemimpinan bergiliran di antara anggota tim?

Perawatan pasien / klien / keluarga / yang berpusat pada komunitas:

Apakah pasien / klien / keluarga anggota tim? 
Bagaimana tim bermitra dengan pasien / klien / keluarga?

Bagaimana informasi dibagikan dengan pasien / klien / keluarga?

Komunikasi antarprofesional:

Seberapa efektifkah komunikasi antara anggota tim?

Bagaimana rencana perawatan bersama dikembangkan?

Fungsi tim:

Apa dinamika kelompok?

Apakah tim merefleksikan fungsinya sebagai tim?

Mengevaluasi Kompetensi Interprofessional

Mengevaluasi Ada peningkatan penekanan pada kebutuhan untuk terlibat dalam penilaian berbasis kompetensi tidak hanya untuk keterampilan praktik klinis, tetapi juga untuk keterampilan kolaborasi interprofesional. Banyak profesi sekarang termasuk perawatan pasien / klien / keluarga / yang berpusat pada masyarakat dan keterampilan kolaborasi antarprofesional pada formulir evaluasi praktikum / kerja lapangan mahasiswa mereka.

Ada sejumlah instrumen yang tersedia untuk menilai kompetensi di bidang kolaborasi antarprofesional, termasuk:

Survei Pencapaian Kompetensi Kolaboratif Interprofessional (ICCAS), yang merupakan alat penilaian mandiri berdasarkan kompetensi yang diidentifikasi dalam Kerangka Kompetensi Interprofesional Interprofesional Nasional CIHC. Sebagai pembimbing, Anda dapat meminta siswa untuk merenungkan dan menilai pencapaian mereka dari kompetensi interprofesional melalui penyelesaian survei ini. http://ennovativesolution.com/WeLearn/IPEEN/ICCAS.Final.pdf.

Rubrik Penilaian Kolaborator Interprofesional (ICAR), yang merupakan alat penilaian berbasis kompetensi yang dapat digunakan untuk penilaian formatif atau sumatif dari kompetensi kolaborator antarprofesional. http://www.med.mun.ca/getdoc/b78eb859-6c13-4f2f-9712f50f1c67c863/ICAR.aspx

\section{REFERENCES}

[3] A. Pragholapati and F. Munawaroh, "Resiliensi pada lansia," J. Surya

Muda, vol. 2, no. 1, pp. 1-8, 2020.

[4] A. Pragholapati, F. Munawaroh, Stik. Jenderal Achmad Yani, and Stik.

Bhakti Kencana Bandung, "RESILIENSI PADA LANSIA,"

ejurnal.ars.ac.id, vol. 2, no. 1, p. 2020.

[5] A. Pragholapati, "RESILIENSI PADA KONDISI WABAH COVID-19," 2020.

[6] A. Pragholapati, F. Munawaroh, Stik. Jenderal Achmad Yani, and Stik.

Bhakti Kencana Bandung, "RESILIENSI PADA LANSIA,"

ojs.stikesmuhkendal.ac.id, vol. 2, no. 1, p. 2020.

[7] A. Pragholapati, "Hubungan masalah kesehatan jiwa dengan strategi koping seseorang yang mengalami perceraian di kota bandung," 2016.

[8] A. Pragholapati and W. Ulfitri, "Gambaran Mekanisme Coping pada Mahasiswa Program Studi Sarjana Keperawatan Tingkat IV yang Sedang Menghadapi Tugas Akhir di Sekolah Tinggi Ilmu Kesehatan X Bandung," 
Humanit. (Jurnal Psikologi), vol. 3, no. 2, pp. 115-126, 2019.

[9] A. Pragholapati, R. S. Oktapiani, and Efri Widianti, "Pengaruh Brain Gym Terhadap Tingkat Depresi Pada Lansia Di Balai Perlindungan Sosial Tresna Werdha Ciparay Bandung," Sk. keperawatan, vol. 5, no. 2, pp. 128 146, 2019.

[10] A. Pragholapati, U. Padjadaran, and F. Keperawatan, "PERAWAT YANG BEKERJA DI UNIT GAWAT DARURAT ( UGD ) RUMAH SAKIT AL ISLAM ( RSAI ) BANDUNG THE CORRELATION OF RESILIENCY WITH NURSE' S WORK STRESS IN EMERGENCY UNIT RUMAH SAKIT AL ISLAM ( RSAI ) BANDUNG,” 2010.

[11] A. Ariani et al., "INFORMATION COMMUNICATION TECHNOLOGY ( ICT ) IN MIDWIFERY EDUCATION ( A REVIEW OF THE LITERATURE )," vol. 3, no. 1, pp. 2014-2017, 2019.

[12] A. Pragholapati, “COVID-19 IMPACT ON STUDENTS,” pp. 1-6, 2020.

[13] A. Pragholapati, "Self-Efficacy Of Nurses During The Pandemic Covid19," no. May 2020, p. 2020.

[14] A. Pragholapati, "HUBUNGAN BULLYING DENGAN KEMAMPUAN SOSIAL PADA REMAJA DI SMK X KOTA BANDUNG," vol. 9, no. 1, pp. $34-40,2020$

\section{REFERENCES}

[1] Ariani, A., Pragholapati, A., \& Pratama, A. S. (2019). INFORMATION COMMUNICATION TECHNOLOGY (ICT) IN MIDWIFERY EDUCATION (A REVIEW OF THE LITERATURE). In The 3rd International Seminar on Global Health (Vol. 3, No. 1, pp. 66-69).

[2] Andria Pragholapati, R. (2018). DEVELOPMENT OF THE INDONESIAN NATIONAL QUALIFICATIONS FRAMEWORK FOR NURSING CURRICULUM. In International Conference on Education and Regional Development 3rd (ICERD) (p. 44).

[3] Pragholapati, A. (2020). COVID-19 IMPACT ON STUDENTS.

[4] Pragholapati, A. (2020). Self-Efficacy Of Nurses During The Pandemic Covid-19.

[5] Pragholapati, A., \& Munawaroh, F. (2020). Resiliensi pada lansia. Jurnal Surya Muda| Jurnal STIKES Muhammadiyah Kendal, 2(1), 1-8.

[6] Pragholapati, A. (2020). MENTAL HEALTH IN PANDEMIC COVID-19. Available at SSRN, 3596311.

[7] Andria Pragholapati, M. L. (2017). HUBUNGAN MASALAH KESEHATAN JIWA DENGAN STRATEGI KOPING SESEORANG YANG MENGALAMI PERCERAIAN DI KOTA BANDUNG. In Seminar Nasional Dan Workshop Keperawatan "Penguatan Profesi Keperawatan Dalam Peningkatan Pelayanan Keperawatan" Continuum of Care Dari Ketergantungan Menuju Kemandirian Hidup Yang Berkualitas.

[8] Pragholapati, A. (2019). THE EFFECT OF BRAIN GYM TO THE LEVEL OF DEPRESSION IN GERIATRIC AT BALAI PERLINDUNGAN SOSIAL TRESNA WERDHA CIPARAY BANDUNG. Jurnal Skolastik Keperawatan, 5(2), 128-146. 
[9] Pragholapati, A. (2020). New Normal "Indonesia" After Covid-19 Pandemic.

[10] Andria Pragholapati, T. (2018). HUBUNGAN PENGGUNAAN SMARTPHONE DENGAN KUALITAS TIDUR PADA REMAJA DI SMK X BANDUNG. Konferensi Nasional Keperawatan Kesehatan Jiwa XV Di Hotel Four Point By Sheraton Makassar Sulawesi Selatan, 1-7.

[11] Andria Pragholapati, R. M. (2017). HUBUNGAN BULLYING DENGAN KEMAMPUAN SOSIAL PADA REMAJA DI SMK MVP KOTA BANDUNG TAHUN 2017. Konferensi Nasional Keperawatan Kesehatan Jiwa XIV Di Kalimantan Selatan Tahun.

[12] Pragholapati, A. (2020). Depression in Someone Who Has Divorce.

[13] Pragholapati, A. (2020). The Role of Nurses in Divorce.

[14] Pragholapati, A. (2020). Anxiety in Someone Who Has Divorce.

[15] Pragholapati, A. (2020). Marriage and Divorce.

[16] Pragholapati, A. (2020). Mental Health Issues Someone Who Has Divorce.

[17]Pragholapati, A. (2020). George A. Beauchamp.

[18] Pragholapati, A. (2020). DEVELOPMENT OF CURRICULUM OF HIGHER EDUCATION (3 COUNTRIES).

[19] Pragholapati, A. (2020). DEVELOPMENT OF HIGHER EDUCATION CURRICULUM IN MALAYSIA EDUCATION DEVELOPMENT OF HIGHER EDUCATION CURRICULUM IN MALAYSIA EDUCATION SYSTEMS.

[20] Pragholapati, A. (2020). DEVELOPMENT OF HIGHER EDUCATION CURRICULUM IN THAILAND EDUCATION SYSTEM.

[21] Pragholapati, A. (2020). Coping Strategies for Someone Divorced.

[22] Pragholapati, A. (2020). DEVELOPMENT OF HIGHER EDUCATION CURRICULUM IN SINGAPORE EDUCATION SYSTEM.

[23] Pragholapati, A. (2020). GOVERNANCE IN MENTAL HEALTH NURSING. PsyArXiv. June, 13.

[24] Pragholapati, A. (2020). Parent Anxiety Levels In Hospitalization Children In RSUD Majalaya Kab. Bandung. Health Media, 1(2), 40-44.

[25] Ariani, A., Destyana, A., \& Pragholapati, A. (2020). GAMBARAN DUKUNGAN SUAMI TENTANG PROGRAM PERENCANAAN PERSALINAN DAN PENCEGAHAN KOMPLIKASI. Jurnal Maternitas Aisyah (JAMAN AISYAH), 1(2), 87-91.

[26] Pratama, A. S., Pragholapati, A., \& Nurrohman, I. (2020). Mekanisme Koping pada Pasien Gagal Ginjal Kronik yang menjalani Hemodialisis di Unit Hemodialisa RSUD Bandung. Jurnal Smart Keperawatan, 7(1), 18-21.

[27] PRAGHOLAPATI, A., \& Sarinengsih, Y. (2019). TINGKAT KECEMASAN PADA PASIEN ANAK USIA SEKOLAH (6-12 TAHUN) DI RUANG IGD RSUD MAJALAYA KABUPATEN BANDUNG. Bali Medika Jurnal, 6(1), 1-7.

[28] Pragholapati, A. (2020). GAMBARAN SESEORANG YANG BERCERAI DI KOTA BANDUNG. Jurnal Skolastik Keperawatan, 6(1), 42-48.

[29] Pragholapati, A. RESILIENSI PADA KONDISI WABAH COVID-19. 
[30] Pragholapati, A. (2020). RESILIENSI PERAWAT YANG BEKERJA DI UNIT GAWAT DARURAT (UGD) RUMAH SAKIT AL ISLAM (RSAI) BANDUNG.

[31] Pragholapati, A. (2020). STRES KERJA PERAWAT YANG BEKERJA DI UNIT GAWAT DARURAT (UGD) RUMAH SAKIT AL ISLAM (RSAI) BANDUNG.

[32] Pragholapati, A. (2020). MOTIVASI KERJA PERAWAT DI RUANG RAWAT INAP RSUD MAJALAYA KABUPATEN BANDUNG.

[33] Rohayani, L., Inayah, I., Shoumi, A. S., \& Pragholapati, A. (2020). Pelayanan Prima Perawat Berdasarkan Persepsi Pasien di Ruang Rawat Inap Talaga Bodas (Penyakit Dalam Pria Kelas 3) Rumah Sakit Tingkat II 03.05. 01 Dustira Cimahi 2019. Journal Of Health Science (Jurnal Ilmu Kesehatan), 5(1), 42-46.

[34] Hadiansyah, T., \& Pragholapati, A. (2020). KECEMASAN KELUARGA DALAM MERAWAT KLIEN SKIZOFRENIA. Jurnal Keperawatan'Aisyiyah, 7(1), 25-29. 